\title{
Workshop: Best-practice for laboratory testing low-permeable materials
}

\author{
Ben Laurich $^{1}$, Jürgen Hesser ${ }^{1}$, Sibylle Mayr ${ }^{1}$, Lisa Winhausen ${ }^{2}$, Amin Ghanizadeh ${ }^{3}$, Antonia Nitsch ${ }^{4}$, \\ Julia Leuthold $^{5}$, Christian Weber ${ }^{1}$, and Garri Gaus ${ }^{6}$ \\ ${ }^{1}$ Federal Institute for Geosciences and Natural Resources, Hanover, Germany \\ ${ }^{2}$ Institute for Engineering Geology and Hydrogeology, RWTH-Aachen University, Aachen, Germany \\ ${ }^{3}$ Department of Geosciences, University of Calgary, Calgary, Canada \\ ${ }^{4}$ Institute for Soil Mechanics, Foundation Engineering and Environmental Geotechnics, \\ University Bochum, Bochum, Germany \\ ${ }^{5}$ Institute for Soil and Rock Mechanics, Karlsruhe Institute of Technology, Karlsruhe, Germany \\ ${ }^{6}$ Institute for Geology and Geochemistry of Petroleum and Coal, RWTH-Aachen University, Aachen, Germany
}

Correspondence: Ben Laurich (ben.laurich@bgr.de)

Published: 10 November 2021

\begin{abstract}
The testing of low-permeable materials is challenging. Yet, for the disposal of radioactive waste, it is essential, too. This workshop is aimed at gathering ambitious scientists to discuss and to collaborate on their experiences in the laboratory testing of low-permeable materials. The focus here is on the methods:
\end{abstract}

1. What method is best for what kind of low-permeable host rock (salt/clay) and for what kind of technical barrier material (bentonite/crushed salt)?

2. How can measurement errors be correctly determined?

3. What are the crucial "bottlenecks" in the device setups?

4. How can high porous but low permeable samples best be pre-saturated?

5. How can coupled flow and cumbersome gas traps in the tests be dealt with?

6. What is the best-practice analysis of permeability from pressure decay recordings?

7. Is there a hope of defining a standardized procedure for low-permeability testing?

These points will be reflected in the light of radioactive waste disposal and in the need to find a best-practice solution when it comes to eventual evaluation and comparison of potential underground disposal sites.

Kurzfassung. Die Prüfung von Materialien mit geringer Durchlässigkeit stellt eine Herausforderung dar. Für die Entsorgung radioaktiver Abfälle jedoch ist sie unabdingbar. Ziel dieses Workshops ist es, ambitionierte Wissenschaftler zusammenzubringen, um ihre Erfahrungen bei der labortechnischen Prüfung von Materialien mit geringer Durchlässigkeit zu diskutieren und hierbei zusammenzuarbeiten. Dabei liegt der Fokus auf folgenden Methoden:

1. Welches Verfahren eignet sich am besten für welches gering durchlässige Wirtsgestein (Salz/Ton) und für welches technische Barrierematerial (Bentonit/Salzgrus)?

2. Wie können Messfehler richtig bestimmt werden?

3. Was sind die entscheidenden „Engpässe“ in den Geräteaufbauten?

4. Wie können hochporöse, aber niedrigpermeable Proben am besten vorgesättigt werden?

5. Wie kann am besten mit gekoppelten Strömungen und lästigen Gasfallen in den Tests umgegangen werden? 
6. Welches ist die beste Vorgehensweise, um die Permeabilität mittels Druckabfallaufzeichnungen zu ermitteln?

7. Besteht die Möglichkeit, ein Standardverfahren für die Prüfung auf geringe Permeabilität zu definieren?

Diese Punkte werden vor dem Hintergrund der Endlagerung radioaktiver Abfälle und der Notwendigkeit, eine optimale Vorgehensweise für die eventuelle Bewertung und den Vergleich potenzieller unterirdischer Endlagerstätten zu finden, reflektiert. 